\title{
Rye Living Mulch Effects on Soil Moisture and Weeds in Asparagus
}

\author{
Daniel C. Brainard ${ }^{1}$ \\ Department of Horticulture, Michigan State University, A440 A Plant and \\ Soil Sciences Building, East Lansing, MI 48824
}

John Bakker

Michigan Asparagus Advisory Board, P.O. Box 550, 12800 Escanaba Drive, Suite A, DeWitt, MI 48820

\section{Corey Noyes \\ Department of Horticulture, Michigan State University, 446 Plant and Soil Sciences Building, East Lansing, MI 48824}

\section{Norm Myers \\ Michigan State University Extension, Oceana County Extension Office, 210 Johnson Street, Hart, MI 49420}

Additional index words. cover crops, weed management, drought stress, irrigation

Abstract. Living mulches growing below asparagus (Asparagus officinales) fern can improve soil health and suppress weeds but may also suppress asparagus through competition for water or nutrients. The central objective of this research was to test whether cereal rye (Secale cereale) living mulch, in combination with overhead irrigation, could provide comparable weed suppression to standard residual herbicides without reducing asparagus yields. A field experiment was conducted from 2008 to 2010 in a mature asparagus planting on sandy soils in western Michigan to evaluate the effects of irrigation (none vs. overhead) and weed management systems (standard herbicides vs. rye living mulch) on weed suppression, soil moisture content, and asparagus yield. Rye living mulch and herbicide treatments were established immediately after asparagus harvest in late June of each year. Rye living mulch reduced soil-available water in early August by $\mathbf{2 6 \%}$ to $52 \%$ compared with herbicide treatments but had no detectable effect on asparagus yields. Compared with herbicide treatments, rye living mulch reduced fall-germinating weed emergence and resulted in lower densities of horseweed (Conyza canadensis) during asparagus harvest. However, in 2 of 3 years, the living mulch system resulted in higher densities of summer annual weeds-including Powell amaranth (Amaranthus powellii) and longspine sandbur (Cenchrus longispinus) - during the fern growth period compared with herbicide treatments. After 3 years, the density of summer annual weeds was more than 10-fold greater in rye living mulch treatments compared with standard residual herbicides treatments. Our results suggest that 1 ) soil-improving rye cover crops can partially suppress weeds but may also compete with asparagus for soil moisture in dry years unless irrigation is used; and 2) successful use of rye living mulches for weed management will depend on identification of complementary weed management practices to avoid build-up of the summer annual weed seedbank.

Cover crops growing below crop canopies provide several potential benefits in vegetable cropping systems. During extreme rainfall

Received for publication 12 Sept. 2011. Accepted for publication 9 Nov. 2011.

Funding for this research was provided by MSU MAES Project GREEEN (GR08-032), the Michigan Department of Agriculture (Specialty Crop Research Block Grant \# 791N1300097), the Michigan Asparagus Research, Inc., and the Michigan Vegetable Council.

The helpful advice and assistance of Steve Dillingham, Ben Byl, Tom Oomen, Dan Drost, and Daryl Lederle are much appreciated. We also acknowledge Bernard Zandstra and Mathieu Ngouajio for their helpful suggestions on previous versions of the manuscript.

${ }^{1}$ To whom reprint requests should be addressed; e-mail brainar9@msu.edu. insect pests (Andow et al., 1986; Vandermeer, 1989), and suppression of weeds (Liebman and Dyck, 1993; Teasdale, 1998).

Despite these potential benefits, living mulches have not been widely adopted in vegetable cropping systems attributable in part to their tendency to either compete directly with the crop or compromise weed management (Brainard and Bellinder, 2004; Teasdale, 1998). When compared with untreated controls, living mulches often suppress weeds (Liebman and Dyck, 1993). However, when compared with common grower practices like herbicides or cultivation, living mulches often result in higher weed density or biomass or reduced crop yields resulting from interference from the cover crop (Teasdale, 1998). Greater adoption of cover crops as living mulches depends critically on identification of strategies for uncoupling weed and crop suppression (Brainard and Bellinder, 2004; Teasdale, 1998).

Competition for water is often cited as a problem where living mulches are used. For example, in unirrigated soybeans (Glycine max), interseeded winter rye (Secale cereale) effectively suppressed weeds without suppressing the crop in years where rainfall was adequate but reduced crop yields in low rainfall years attributable in part to competition for soil moisture (Ateh and Doll, 1996; Robinson and Dunham, 1954). Conversely, in irrigated broccoli (Brassica oleracea), rye living mulches sown $10 \mathrm{~d}$ or more after transplanting had no negative effect on crop yield (Brainard and Bellinder, 2004).

Although asparagus is deep-rooted and relatively drought-tolerant, competition for moisture or nutrients from a living mulch may be detrimental to asparagus in dry years. Numerous studies have shown that inadequate moisture during asparagus fern growth can reduce production and storage of soluble carbohydrates and ultimately reduce crop quality and yields (Drost and Wilcox-Lee, 1997; Hartmann, 1981; Paschold et al., 2004; Roth and Gardner, 1990). In addition, drought stress in asparagus may indirectly reduce asparagus quality and yield by reducing its resilience to insects and pests. For example, drought-stressed asparagus is more susceptible to fusarium species, which cause crown and stem rot in asparagus (Nigh, 1990).

Rye living mulches, sown immediately after asparagus harvest, have been recommended (e.g., Kuepper and Thomas, 2001) and tried by growers, but few studies have evaluated their impact on asparagus or weeds. In events, these "living mulches" protect the soil from degradation and reduce the risks of nutrient and pesticide runoff. Living mulches may also provide a range of other benefits, including mitigation of soil compaction, increases in soil organic matter, improved nutrient cycling, reductions in the incidence of
Table 1. Summary of management during fern growth period.

\begin{tabular}{lllll}
\hline Treatment & \multicolumn{1}{c}{ Residual herbicides } & Living mulch & Tillage & Irrigation \\
\hline $\begin{array}{l}\text { Conventional } \\
\text { Not irrigated }\end{array}$ & S-metalochlor/sulfentrazone & None & None & None \\
$\begin{array}{l}\text { Irrigated } \\
\text { Living mulch }\end{array}$ & S-metalochlor/sulfentrazone & None & None & Overhead $^{\mathrm{x}}$ \\
$\begin{array}{l}\text { Not irrigated } \\
\text { Irrigated }\end{array}$ & None & & & \\
\hline
\end{tabular}

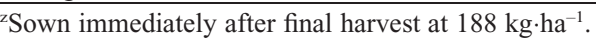

${ }^{\text {y }}$ Shallow rototilling to incorporate rye and kill emerged weeds.

"Applied from June to mid-August (see "Materials and Methods"). 
Wisconsin, living mulches grown in unirrigated asparagus provided weed suppression benefits but also significantly reduced asparagus yields (Paine et al., 1995). In many asparagus production regions, cover crops are sown below the asparagus fern shortly before fern senescence to take up excess nutrients that would otherwise be lost to leaching as well as to protect the soil from wind and rain erosion. For example, Paschold et al. (1999) report that in Germany, oilseed radish (Raphanus sativus var oleiforis L.) grown under asparagus fern from August to October reduces vulnerability to leaching by taking up as much as $50 \%$ of residual soil nitrogen compared with non-cover crop treatments with no detectable effect on crop yields. In the midwestern United States, winter rye is often sown in late August or September below the asparagus fern to help provide protection from wind and water erosion. In Michigan in recent years, several large commercial asparagus growers have been experimenting with winter rye living mulches sown in combination with shallow tillage immediately after asparagus harvest in early July. They believe that this system may reduce the need for residual herbicides that have the potential to damage the developing asparagus fern.

The central objective of this research was to test whether rye living mulch, in combination with overhead irrigation, could provide comparable weed suppression to standard residual herbicides without reducing asparagus yields. Important secondary objectives included 1) evaluating potential beneficial effects of irrigation on asparagus yields; and 2) evaluating the impact of winter rye living mulch on soil moisture content. We hypothesized that rye living mulches would interfere with weed growth but, in the absence of irrigation, would also compete with the asparagus crop for soil moisture.

\section{Materials and Methods}

A field trial was initiated at the Asparagus Research Farm in Hart, MI, in asparagus (cultivar Jersey Giant) that had been established from crowns in 1999. The soil type at the experimental site was a Spinks loamy-fine sand $(85 \%$ to $91 \%$ sand) with available water capacity in the rooting zone ranging from $\approx 0.04$ to $0.06 \mathrm{~cm} \cdot \mathrm{cm}^{-1}$.

After the final asparagus harvest on 25 June 2008, four experimental treatments were established consisting of two different weed management systems (conventional vs. living mulch), each with two levels of irrigation (no irrigation vs. irrigation) (Table 1). The same management systems were maintained in the same plots through the 2010 growing season with yield data taken in 2009 and 2010 .

Six replicates of each treatment were arranged in a randomized complete block design in plots measuring $7.6 \times 4.1 \mathrm{~m}$ with three rows of asparagus spaced $1.4 \mathrm{~m}$ apart in each plot. In all treatments, herbicide applications before harvest in late April consisted of glyphosate (1.12 kg ai/ha), s-metalochlor (1.07 kg ai/ha), and linuron $(0.84 \mathrm{~kg}$ ai $/ \mathrm{ha})$. After harvest in late
Table 2. Mean monthly temperature and rainfall, 2008-2010, Hart, MI.

\begin{tabular}{lrrrrrrrrr}
\hline & \multicolumn{4}{c}{ Temp. $\left({ }^{\circ} \mathrm{C}\right)$} & & \multicolumn{4}{c}{ Rainfall $(\mathrm{cm})$} \\
\cline { 2 - 4 } \cline { 8 - 9 } & 2008 & 2009 & 2010 & $30-\mathrm{yr}$ & & 2008 & 2009 & 2010 & $30-\mathrm{yr}$ \\
\hline April & 8.5 & 6.9 & 10.1 & 6.4 & & 10.01 & 9.42 & 6.81 & 7.35 \\
May & 10.8 & 13.0 & 14.1 & 12.8 & & 2.41 & 12.08 & 4.20 & 7.76 \\
June & 18.3 & 17.0 & 19.0 & 18.1 & & 13.93 & 9.27 & 12.93 & 8.42 \\
July & 20.6 & 17.5 & 22.0 & 20.6 & & 7.27 & 2.48 & 10.88 & 7.27 \\
August & 19.5 & 19.5 & 22.0 & 19.4 & & 4.86 & 9.80 & 7.91 & 10.47 \\
September & 16.8 & 16.6 & 16.9 & 15.3 & & 8.76 & 5.07 & 7.45 & 9.86 \\
\hline
\end{tabular}

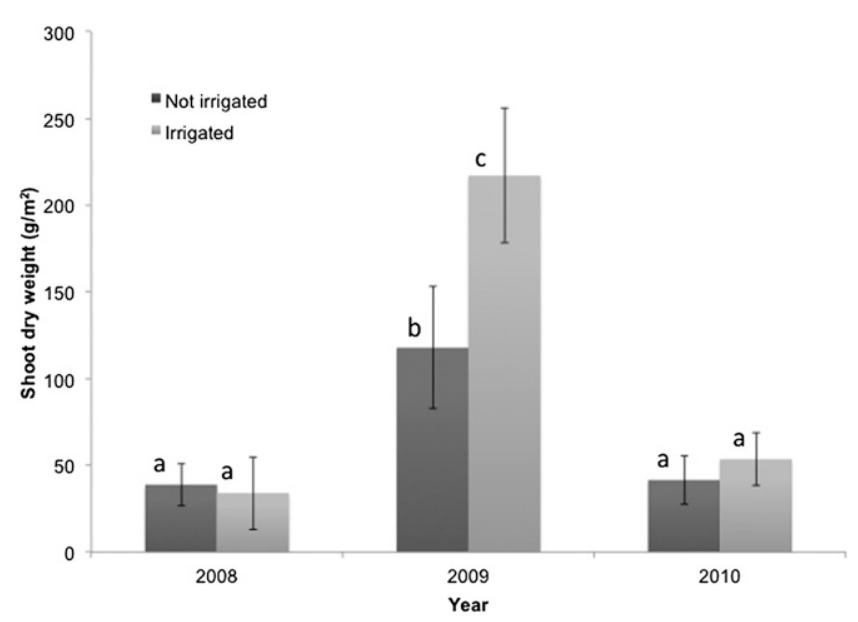

Fig. 1. Mean $( \pm \mathrm{SE})$ volumetric water content under conventional vs. living mulch systems, with and without irrigation, at $15 \mathrm{~cm}$ (upper) and $60 \mathrm{~cm}$ (lower); and rainfall (dark bars) and irrigation (light bars) (lower), 2010.
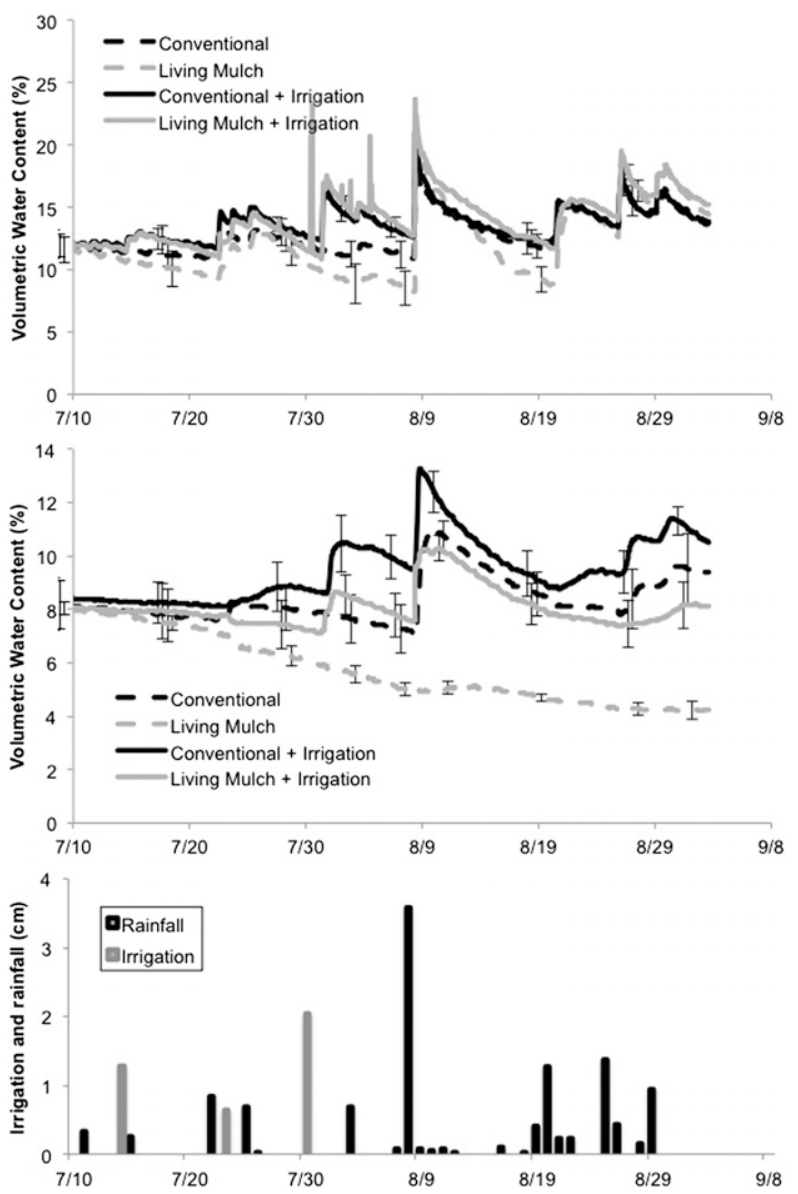

Fig. 2. Mean ( $( \pm \mathrm{SE})$ rye shoot dry weight in irrigated vs. non-irrigated treatments, 2008-2010. Mean values with different letters were significantly different according to Fishers' protected least significant difference test at $P<0.05$. 

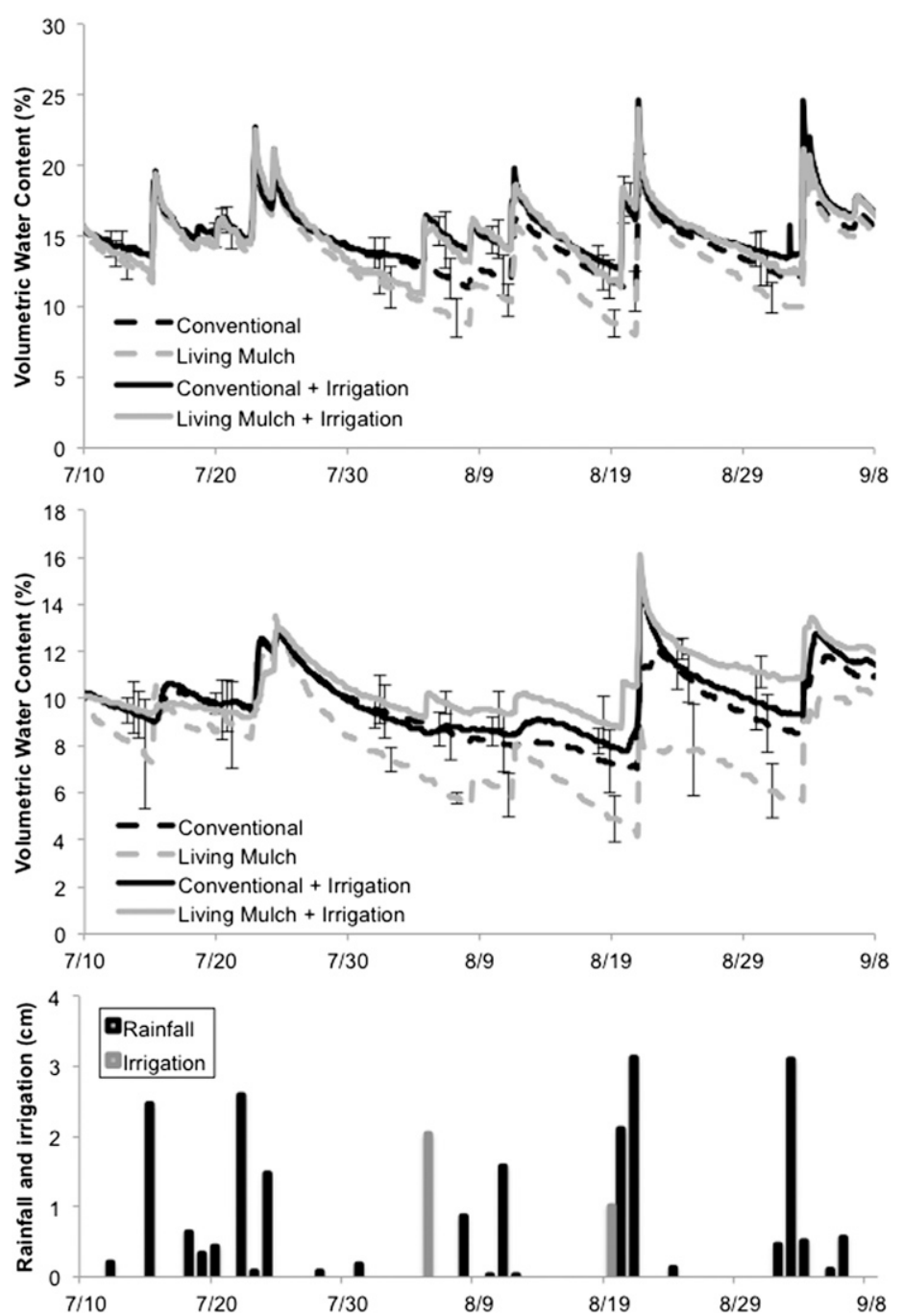

Fig. 3. Mean ( $\pm \mathrm{SE})$ volumetric water content under conventional vs. living mulch systems, with and without irrigation, at $15 \mathrm{~cm}$ (upper) and $60 \mathrm{~cm}$ (middle); and rainfall (dark bars) and irrigation (light bars) (lower), 2008.

June, herbicides applied to conventional systems consisted of a standard herbicide program of glyphosate $(1.12 \mathrm{~kg}$ ai/ha), s-metalochlor (1.07 kg ai/A), sulfentrazone $(0.14 \mathrm{~kg}$ ai $/ \mathrm{ha})$, and diuron (1.075 kg ai $/ \mathrm{ha})$. In the living mulch system, glyphosate $(1.12 \mathrm{~kg}$ ai/ha) was applied immediately after harvest, but no additional herbicides were used; $3 \mathrm{~d}$ after glyphosate application, winter rye was broadcast at $188 \mathrm{~kg} \cdot \mathrm{ha}^{-1}$ and incorporated to a depth of $1-4 \mathrm{~cm}$ with a rototiller. No postemergence herbicides were used in either system during the fern growth period. All applications were made at 234 $\mathrm{L} \cdot \mathrm{ha}^{-1}$ at $207 \mathrm{kPa}$ with a $\mathrm{CO}_{2}$ backpack sprayer equipped with Teejet VS-8002 nozzles.

Overhead irrigation was accomplished using Hunter MP2000 rotary sprinklers. Soil moisture sensors (EC-5 sensors; Decagon Devices) were installed at $15-\mathrm{cm}$ and $60-\mathrm{cm}$ depths in four replicates of each treatment to monitor soil volumetric water content (VWC). In irrigated treatments, irrigation was used initially to establish rye and then applied when VWC at $60 \mathrm{~cm}$ fell below $8 \%$ in the conventional irrigated treatment. In irrigation experiments in similar soils, $8 \%$ VWC at $60 \mathrm{~cm}$ corresponded to $\approx 50 \%$ available water measured to a depth of $1 \mathrm{~m}$. The same level of irrigation was applied to irrigated plots in both rye living mulch and conventional weed management systems. Irrigation was discontinued in mid- to late August to avoid potentially detrimental effects of late-season irrigation. In some studies, late-season irrigation has resulted in yield losses attributed to excessive fern growth at the expense of assimilate accumulation in the root system (e.g., Wilson et al., 1996).

Weed density and rye shoot dry weight were assessed in early September each year. In 2010, weed density was also evaluated on 16 Apr. and 11 June to assess cumulative effects of treatments on weed communities before and during the harvest period. Weed density was evaluated by counting the number of weeds greater than $30 \mathrm{~cm}$ in height (for erect weeds) or diameter (for rosette/spreading weeds) in the entire plot. For dandelion (Taraxacum officinale), the number of seeds produced per square meter was estimated by counting the number of flowers per square meter and multiplying by an estimate of the number of seeds per flower based on a subsample of 10 flowers randomly selected from 10 different individuals. Asparagus yield was assessed from the middle row of each plot during 27 harvests from 5 May to 25 June in 2009 and 25 harvests from 29 Apr. to 16 June in 2010.

The effects of irrigation, cropping system, and their interactions on soil moisture, weed density, weed biomass, and asparagus yields were assessed using the general linear model procedure of SAS (SAS Institute, Cary, NC). Data were transformed as necessary to meet the assumptions of normality and homogeneity of variance. Mean separation was conducted using Fisher's protected least significant difference test at $P<0.05$.

\section{Results and Discussion}

Weather. In 2008, both temperature and rainfall were close to long-term averages throughout the fern growth period with the exception of August, when rainfall was $\approx 5.6$ $\mathrm{cm}$ below average (Table 2). In 2009, during early fern growth (July), temperatures were more than $3{ }^{\circ} \mathrm{C}$ below average and rainfall almost $5 \mathrm{~cm}$ below average. In contrast, weather in 2010 was unusually warm and wet with mean temperatures exceeding longterm averages by $\approx 2{ }^{\circ} \mathrm{C}$ in July and August and timely rains occurring throughout the summer.

Rye growth and impact on soil moisture. Rye shoot dry weight in September ranged from $\approx 40$ to $50 \mathrm{~g} \cdot \mathrm{m}^{-2}$ in 2008 and 2010 with no detectable difference in irrigated and nonirrigated treatments (Fig. 1). In contrast, rye shoot dry weight in 2009 was responsive to irrigation, ranging from $118 \mathrm{~g} \cdot \mathrm{m}^{-2}$ in nonirrigated treatments to over $200 \mathrm{~g} \cdot \mathrm{m}^{-2}$ in irrigated treatments. The responsiveness of rye to irrigation in 2009 was likely the result of low rainfall totals during July (Table 2). Greater rye growth in 2009 compared with other years may be partly attributable to cool temperatures that occurred during rye establishment (July) that year (Table 2). In July 2009 , temperatures averaged $17.5^{\circ} \mathrm{C}$, which is more than $3{ }^{\circ} \mathrm{C}$ lower than long-term averages and almost $5{ }^{\circ} \mathrm{C}$ lower than temperatures in 2010. Rye is a cool-season grass with optimal temperature for growth of $\approx 20-25^{\circ} \mathrm{C}$ (Tieszen, 1970). Unusually cool temperatures during July may have given rye a competitive advantage relative to warm-season $\mathrm{C} 4$ weeds including Powell amaranth, which has an optimal temperature for growth of $35{ }^{\circ} \mathrm{C}$ or more (Oryokot et al., 1997).

In all years, the impact of rye living mulch on soil moisture was apparent in early August, $\approx 1$ month after planting (Figs. 2 to 4 ). During the first week of August, soil VWC at $60 \mathrm{~cm}$ in non-irrigated rye living mulch treatments was reduced by $26 \%$ in 2008 (from $6.2 \%$ to $4.6 \%$ ), by $52 \%$ in 2009 (from $10.2 \%$ to $4.9 \%$ ) and by $33 \%$ in 2010 (from $8.6 \%$ to $5.8 \%$ ) compared with non-irrigated conventional treatments (Figs. 2 to 4, middle panels). Greater reductions in soil VWC in rye living mulch treatments in 2009 are consistent with the observation that rye produced far greater biomass in that year than in either 2008 or 2010 (Fig. 1). In 2009, 
irrigation in rye plots brought soil VWC to levels comparable to those observed in non-rye, non-irrigated treatments (Fig. 3) and resulted in a doubling of rye biomass relative to nonirrigated rye (Fig. 1).

Not surprisingly, soil VWC at $15 \mathrm{~cm}$ was more variable than that at $60 \mathrm{~cm}$ with rapid replenishment to field capacity occurring after rainfall events in all treatments (Figs. 2 to 4, upper panels). However, when substantial rainfall did not occur for 1 week or more, reductions in soil VWC at $15 \mathrm{~cm}$ in rye living mulch compared with bare-soil treatments were evident in all years. For example, during
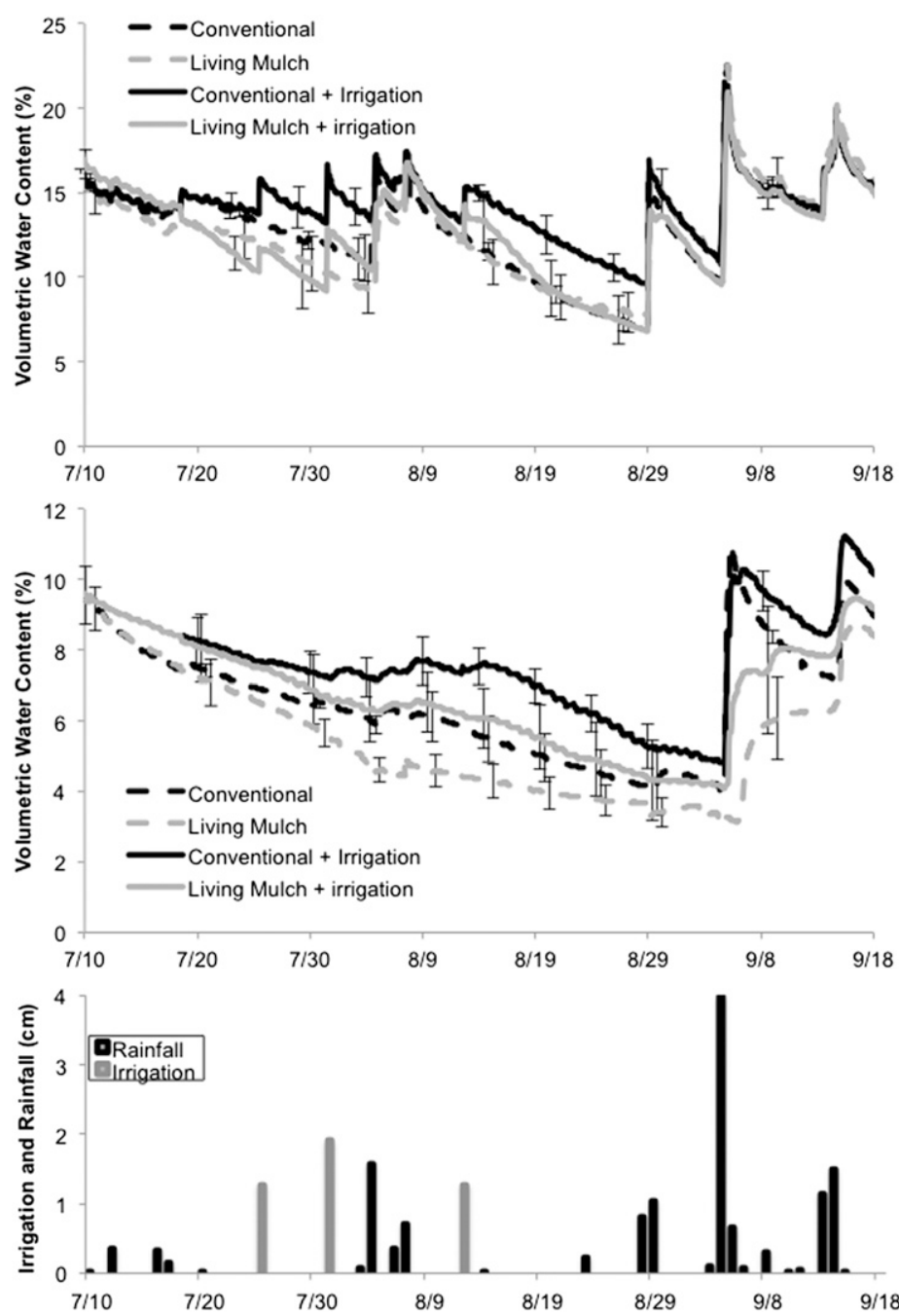

Fig. 4. Mean $( \pm \mathrm{SE})$ volumetric water content under conventional vs. living mulch systems, with and without irrigation, at $15 \mathrm{~cm}$ (upper) and $60 \mathrm{~cm}$ (lower); and rainfall (dark bars) and irrigation (light bars) (middle), 2009.

the 1-week period after rainfall on 11 Aug. 2010, soil VWC in non-irrigated rye living mulch treatments declined by $50 \%$ (from $16 \%$ to $8 \%$ ) compared with a reduction of only $25 \%$ (from $16 \%$ to $12 \%$ ) in non-irrigated conventional treatments (Fig. 4).

Effects of rye on weeds during fern growth. The dominant weed species during fern growth in all 3 years were Powell amaranth and longspine sandbur. In 2008 and 2010, the rye living mulch system resulted in greater densities of both species compared with herbicide treatments (Table 3). Total summer annual weed density in late summer in the rye living mulch treatments was approximately twofold higher in 2008 and 12-fold higher in 2010 compared with the conventional system. In contrast, in 2009, summer annual weed density in the rye living mulch treatment was equivalent to the conventional herbicide treatment.

The ability of rye to suppress weeds in 2009 may be attributed in part to unusually cool conditions that year during rye establishment (Table 2), conditions that strongly favor rye growth relative to warm-season weeds, including Powell amaranth. In previous work, Brainard and Bellinder (2004) demonstrated that the ability of cereal rye to suppress Powell amaranth was enhanced at low initial temperatures. Conversely, failure of rye living mulch to suppress summer annual weeds in 2010 was likely attributable in part to warm temperatures (Table 2), conditions that strongly favored Powell amaranth and longspine sandbur. In addition, high weed densities in rye living mulches in 2010 may have been attributable in part to high seedbank density of these summer annual weed species resulting from weed seed production in 2008. Although weed seed production was not estimated in this study, both Powell amaranth and longspine sandbur were observed to produce seeds in living mulch treatments in both 2008 and 2010. Such seed production would likely increase weed management costs or reduce asparagus yields in subsequent years.

Effects of rye living mulch on weeds before and during harvest. At the time of spring burndown herbicide applications in Apr. 2010, dandelion and horseweed (Conyza canadensis) densities were $96 \%$ and $57 \%$ lower, respectively, in rye living mulch compared with

Table 3. Effects of irrigation and rye on mean weed density in late summer, 2008-2010.

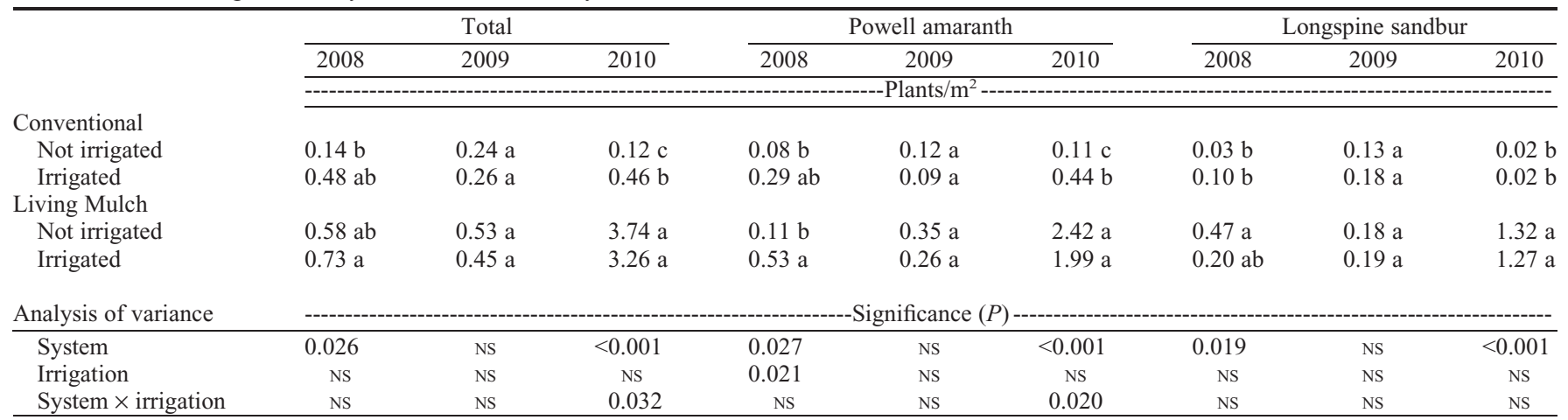

Note: Only weeds greater than $30 \mathrm{~cm}$ in height or diameter were included. Column means with a letter in common are not significantly different (Fisher's least significant difference method; $P=0.05$ ).

NS $=$ non-significant . 
conventional management (Table 4). Dandelion seed production was reduced from over 300 seeds $/ \mathrm{m}^{2}$ in the conventional system to less than one seed $/ \mathrm{m}^{2}$ in the rye living mulch system. The suppressive effect of rye living mulch on these species in 2010 was likely the result of the presence of a thick rye stand in late summer of 2009 (Fig. 1), which may have prevented establishment of these fall germinating species. Germination may have been inhibited through rye-induced reductions in the ratio of red to far red light (Brainard et al., 2005) or through release from rye residue of allelochemical compounds such as [2,4dihydroxy-1,4(2H)-benzoxazin-3-one (DIBOA) (Barnes and Putnam 1987). Alternatively, post-emergence mortality may have been high where rye was present as a result of competition or allelopathy.

Although dandelion was successfully suppressed with spring applications of glyphosate in both cropping systems in 2010, glyphosateresistant horseweed survived, resulting in substantially higher horseweed densities during the harvest period in conventional compared with living mulch treatments (Fig. 5). In contrast, longspine sandbur densities during harvest in 2010 were substantially higher in living mulch treatments compared with conventional treatments, whereas Powell amaranth densities did not differ by system (Fig. 5).

Effects on asparagus. No differences in asparagus yields resulting from either rye or irrigation were observed in this study in either year (Fig. 6). However, high variability in asparagus yields across the experimental area (attributable in part to a patchy infestation of Phytophthora asparagii) limited the statistical power of our study to detect differences in yield. Incidence of Phytophthora appeared to be unrelated to treatment and undoubtedly existed before the experiment was initiated. Although overhead irrigation has the potential to increase the duration of leaf wetness and hence the incidence of diseases such as purple spot, irrigation may improve crop tolerance to disease by reducing stress (Nigh, 1990). Several other factors may help explain why neither rye nor irrigation had a detectable impact on asparagus. First, rainfall during all 3 years of this study may have been sufficient to avoid drought stress. Rainfall totals from June to August were at or above long-term averages in 2008 and 2010 (Table 2). In 2009, rainfall was slightly lower than long-term averages - particularly in July - but unusually cool temperatures (Table 2) limited evapotranspirational demand. It should also be noted that the study was conducted with a mature stand of 'Jersey Giant'. Less droughttolerant varieties, or younger stands with less developed root systems, would likely be more susceptible to competition for water from winter rye.

In summary, our results demonstrate that the effectiveness of rye living mulch as a weed management tool varies with weed species and environmental conditions. Relatively cool temperatures (e.g., 2009) favor the growth and competitive ability of rye relative to

Table 4. Effects of production system and irrigation on weeds, Apr. 2010.

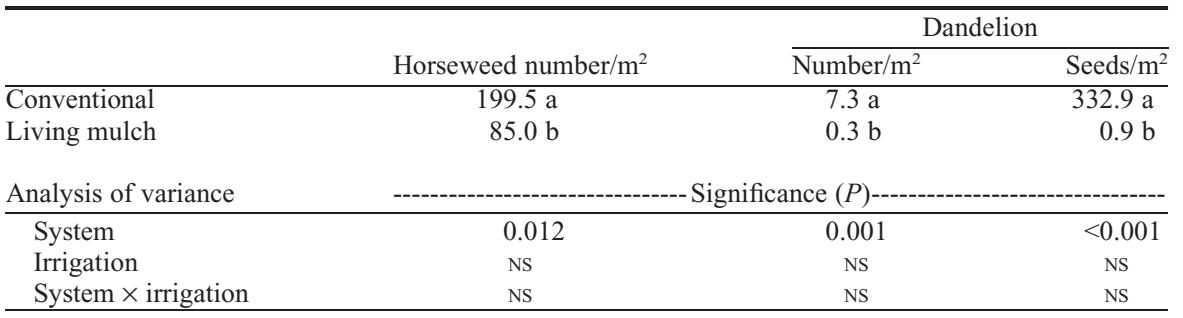

Column means with a letter in common are not significantly different (Fisher's least significant difference method; $P=0.05)$.

NS $=$ non-significant.

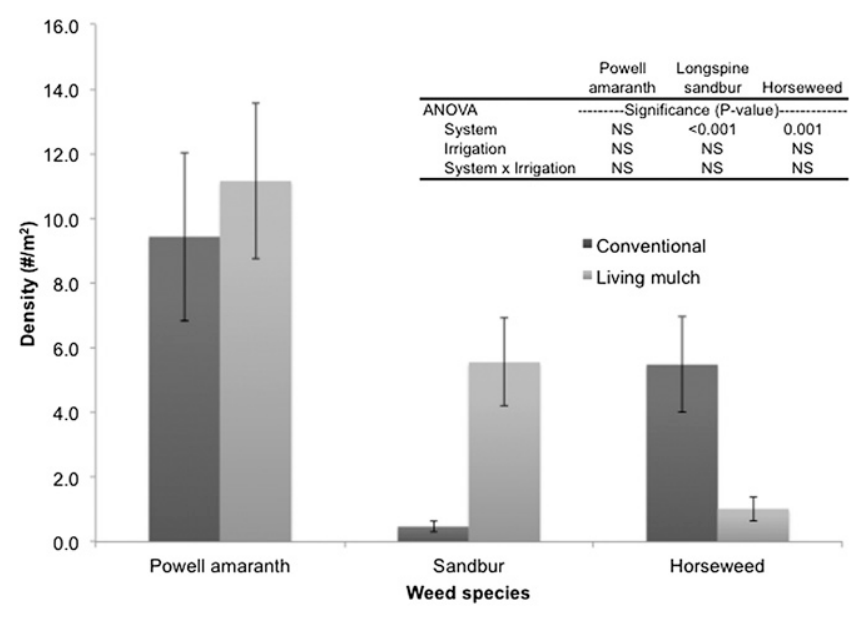

Fig. 5. Mean $( \pm \mathrm{sE})$ weed density under conventional vs. living mulch treatments by species during asparagus harvest, 2010. $P$ values for analysis of variance for effects of system, irrigation, and their interaction are provided by species. Because irrigation and irrigation $\times$ system interactions were not significant, data were combined for each weed management system.

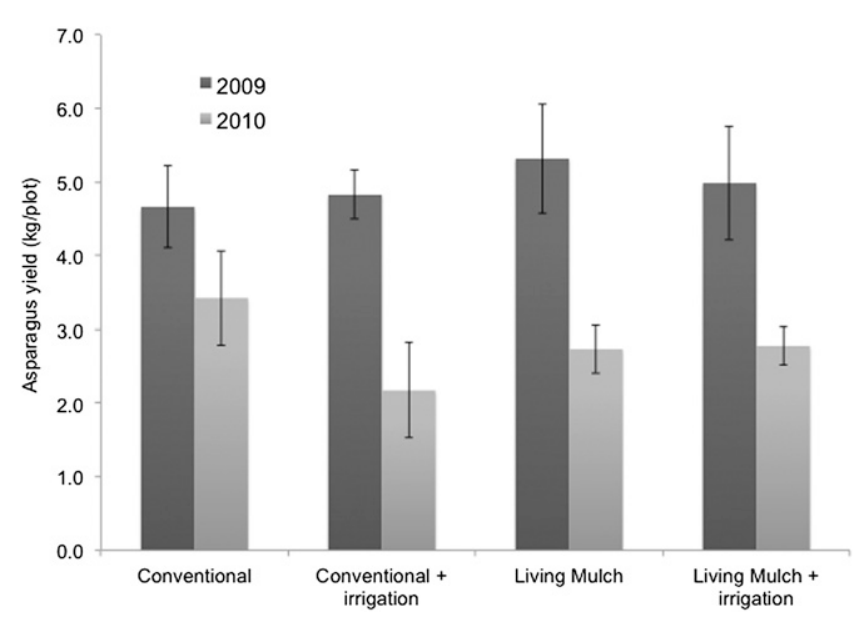

Fig. 6. Mean ( $\pm \mathrm{SE}$ ) asparagus yields under conventional vs. living mulch systems, with and without irrigation, 2009 and 2010. The effects of system, irrigation, and their interactions were not significant in either year; therefore, no mean separation was conducted.

summer annual weeds, including Powell amaranth and longspine sandbur (Table 2). Conversely, warm conditions (e.g., 2010) reduce the effectiveness of rye as a tool for suppression of these species. On the other hand, rye established in midsummer is an effective means of suppressing establishment of latesummer and fall-germinating weed species including horseweed and dandelion (Table 4; Fig. 5). Because horseweed has developed re- sistance to glyphosate, and is not easily controlled with other herbicides, the use of rye living mulch for suppression of this species may be particularly useful. Our results also demonstrate that rye living mulches significantly reduce soil moisture content (Figs. 2 to 4). Observed reductions in soil moisture resulting from rye at $15-\mathrm{cm}$ depth may contribute to its weed-suppressive ability without suppressing asparagus fern growth, because developing 
weeds have much shallower root systems than asparagus. However, reductions in soil moisture resulting from rye at $60 \mathrm{~cm}$ may contribute to drought stress of the developing asparagus fern in dry years and ultimately to yield losses. On the other hand, when rainfall is plentiful or excessive in fall, rye living mulch may help facilitate draw-down of soil moisture and reduce the risk of promoting fern growth at the expense of storage of soluble carbohydrates in roots.

Possible approaches for improving the weed-suppressive ability of winter rye include increased seeding rates, use of complementary herbicides, or combining rye with mixtures of other cover crops. In an on-farm study evaluating rye seed rate effects on weeds in asparagus, increasing the rate from $125 \mathrm{~kg} \cdot \mathrm{ha}^{-1}$ to $188 \mathrm{~kg} \cdot \mathrm{ha}^{-1}$ resulted in an $80 \%$ reduction in Powell amaranth dry weight (Brainard, unpublished data). Registered broadleaf herbicides including halosulfuron are compatible with winter rye living mulches and could have been used to reduce or eliminate Powell amaranth in rye living mulches. However, to our knowledge, no grass herbicides are available that can control longspine sandbur or crabgrass without also killing rye. Finally, mixtures of cover crop species have been shown to improve weed suppression relative to a single species in several studies (reviewed in Liebman and Dyck, 1993) and may also be useful in rye living mulch. Identification of cover crops that establish rapidly under warm temperatures would be particularly beneficial for complementing rye in mixtures. The adoption of living mulches for improving soil health and suppressing weeds in asparagus will likely depend on use of irrigation and adjustments in fertility management to minimize potential interference with asparagus.

\section{Literature Cited}

Andow, D.A., A.G. Nicholson, H.C. Wien, and H.R. Willson. 1986. Insect populations on cabbage grown with living mulches. Environ. Entomol. 15:293-299.

Ateh, C.M. and J.D. Doll. 1996. Spring-planted winter rye (Secale cereale) as a living mulch to control weeds in soybean (Glycine max.). Weed Technol. 10:347-353.

Barnes, J.P. and A.R. Putnam. 1987. Role of benzoxazinones in allelopathy by rye (Secale cereale L.). J. Chem. Ecol. 13:889-906.

Brainard, D.C. and R.R. Bellinder. 2004. Weed suppression in a broccoli-winter rye intercropping system. Weed Sci. 52:281-290.

Brainard, D.C., R.R. Bellinder, and A. DiTommaso. 2005. Effects of canopy shade on morphology, phenology and seed characteristics of Powell amaranth. Weed Sci. 53:175-186.

Drost, D.T. and D. Wilcox-Lee. 1997. Soil water deficits and asparagus: II. Bud size and subsequent spear growth. Sci. Hort. 70:145-153.

Hartmann, H.D. 1981. The influence of irrigation on the development and yield of asparagus. Acta Hort. 119:309-316.

Kuepper, G. and R. Thomas. 2001. Organic asparagus production. Current topic. Appropriate technology transfer for rural areas. National Center for Appropriate Technology. 5 Aug. 2011. $<$ https://attra.ncat.org/attra-pub/PDF/asparagus. pdf $>$.

Liebman, M. and E. Dyck. 1993. Crop rotation and intercropping strategies for weed management. Ecol. Appl. 3:92-122.
Nigh, E.L. 1990. Stress factors influencing fusarium infection in asparagus. Acta Hort. 271:315-322.

Oryokot, J.O.E., A.G. Thomas, and C.J. Swanton. 1997. Temperature- and moisture-dependent models of seed germination and shoot elongation in green and redroot pigweed (Amaranthus powellii and A. retroflexus). Weed Sci. 45: 488-496.

Paine, L., H.C. Harrison, and A.C. Newenhouse. 1995. Establishment of asparagus with living mulch. J. Prod. Agr. 8:1-2.

Paschold, P.J., B. Artelt, and G. Hermann. 1999. Influence of catch crops on leaching, yield and quality of white asparagus. Proceedings from the 9th International Asparagus Symposium. Acta Hort. 479:439-445.

Paschold, P.J., B. Artelt, and G. Hermann. 2004 The water need of asparagus determined in a lysimeter station. Proceedings from the IVth International Symposium on Irrigation of Horticultural Crops. Acta Hort. 664:529-536.

Robinson, R.G. and R.S. Dunham. 1954. Companion crops for weed control in soybean. Agron. J. 46:278-281.

Roth, R.L. and B.R. Gardner. 1990. Asparagus spear size distribution and earliness as affected by water and nitrogen applications. Amer. Soc. Agr. Bio. Eng. 33:480-486.

Teasdale, J.R. 1998. Cover crops, smother plants, and weed management, p. 247-270. In: Hatfield, J.L., D.D. Buhler, and B.A. Stewart (eds.). Integrated weed and soil management. Ann Arbor Press, Chelsea, MI.

Tieszen, L.L. 1970. The effects of simazine and temperature on photosynthesis in rye. Plant Physiol. 46:442-444.

Vandermeer, J. 1989. The ecology of intercropping. Cambridge Univ. Press, New York, NY.

Wilson, D.R., S.M. Sinton, and H.A. Fraser-Kevern. 1996. Irrigation responses of established asparagus. Acta Hort. 415:333-342. 